\title{
CYCLIC IRRIGATION IMPROVES IRRIGATION APPLICATION EFFICIENCY AND GROWTH OF SAWTOOTH OAK
}

\author{
by Glenn B. Fain, Ken M. Tilt, Charles H. Gilliam, Harry G. Ponder, and Jeff L. Sibley
}

\begin{abstract}
Two studies were conducted to evaluate different irrigation regimes for production of container-grown sawtooth oak. Three irrigation treatments (single, 3 times daily, and 6 times daily) and 2 substrate treatments ( $100 \%$ pinebark and $4: 1$ (v:v) pinebark:coir) were evaluated to determine their effects on irrigation application efficiency and growth of sawtooth oak (Quercus acutissima Carruthers) in a pot-in-pot production system. Irrigation application efficiency increased with cyclic treatments compared to a single application and was increased with the pinebark:coir substrate compared to pinebark alone in the single application treatment. Growth was greater when irrigation was applied in 6 cycles than in 1 single application. Trees grown in pinebark:coir substrate were larger than those grown in the pinebark substrate.
\end{abstract}

Key Words. Pot-in-pot; container production; substrate; coconut coir.

This research project was designed to evaluate alternatives to traditional production practices of shade trees for use in the urban landscape. Sawtooth oak (Quercus acutissima Carruthers) is native to eastern Asia, from the Himalayas through China, Korea, and Japan. Sawtooth oak was introduced into the eastern United States in 1862 (Rehder 1940) and adapts well to climates from northern Florida west to eastern Texas and Oklahoma, northward through Missouri, and eastward to New York and southern New England (Gilbert and Henry 1988).

The quality and quantity of water used, along with the leachate leaving container nurseries, is of great concern for nurseries in the United States (McWilliams et al. 1991). With increasing emphasis on water quality, commercial nurseries are being targeted as potential sources of ground and surface water contamination (Evans and Stamps 1996). Although overhead irrigation is inefficient, many containergrown landscape plants are irrigated with overhead sprinklers, especially larger plants (Beeson and Knox 1991). Overhead irrigation may apply 374,000 L/ha daily $(40,000 \mathrm{gal} / \mathrm{ac})$, with losses from $40 \%$ to $90 \%$ through evaporation during application and runoff (Bir 1988).

An alternative to the standard practice of overhead irrigation is cyclic irrigation through a spray stake in each individual container (Martin 1989; Lamack 1993). With cyclic irrigation, a plant's daily water allotment is subdivided into 2 or more applications with prescribed intervals between applications. This contrasts with conventional irrigation practices whereby the daily water allotment is applied in a single application (Karam et al. 1994). Cyclic irrigation may improve application efficiency by allowing water to move through the container substrate (Karam and Niemiera 1994). Irrigation application efficiency improves up to $38 \%$ with cyclic irrigation over single applications (Tyler et al. 1996). In addition to reducing water loss, growers using cyclic irrigation can expect greater plant utilization of applied nitrogen ( $\mathrm{N}$ ) as well as reduced nutrient loss from containers (Karam and Niemiera 1994).

Two studies were conducted to determine the effects of cyclic micro-irrigation and pinebark substrate amended with the peat substitute coconut coir on growth of sawtooth oak as well as irrigation application efficiency in a pot-in-pot production system. Coconut coir is produced from the mesocarp tissue, or husk, of the coconut (Cocus nucifera) fruit. Coir-based substrates have greater water-holding capacities than comparable peat-based substrates (Evans and Stamps 1996). With pot-in-pot production, introduced around 1990 (Parkerson 1990), a "socket" pot is permanently placed in the ground. The container holding the plant is then placed inside the "socket" pot.

\section{MATERIALS AND METHODS Experiment 1}

Ninety-six uniform bare-root liners, 46 to $60 \mathrm{~cm}$ (18 to 24 in.), of sawtooth oak were planted in \#15 [56 L (15 gal)] "GripLip" containers (Nursery Supplies, 
Fairless Hills, PA) in April 1996 in a randomized complete block design with 8 blocks. All treatments ( 2 substrates $\times 2$ fertilizer $\times 3$ irrigation) were assigned to each block. The substrates were 1) $100 \%$ pinebark and 2) 4:1 (v:v) pinebark:coconut coir. Substrate physical properties (Table 1) were determined using the North Carolina State University Porometer (Fonteno et al. 1995). Both substrates were amended with $3.5 \mathrm{~kg} / \mathrm{m}^{3}\left(6 \mathrm{lb} / \mathrm{yd}^{3}\right)$ of dolomitic limestone. Trees were topdressed with either 179 or $358 \mathrm{~g}$ (6.3 or $12.6 \mathrm{oz}$ ) of an 8- to 9-month controlled release fertilizer (Sierra 17-6-10 plus minors, O.M. Scotts Co. Inc., Marysville, $\mathrm{OH}$ ).

The 3 irrigation treatments were 1) $2,160 \mathrm{~mL}$ (72.9 oz) of water in a single application at 10:00 A.M.; 2) 2,160 mL of water applied divided into 3 applications, at 10:30 A.M., 1:00 P.M., and 3:30 P.M.; and 3) $2,160 \mathrm{~mL}$ of water divided into 6 applications, at 8:00 A.M., 9:30 A.M., 11:00 A.M., 12:30 P.M., 2:00 P.M., and 3:30 P.M. Irrigation was applied through maxi-jet spray stakes attached to a Bosmith pressure compensating emitter (Acuff Irrigation Company, Cottondale, FL) at a rate of $400 \mathrm{~mL}(13.5 \mathrm{oz})$ per minute. Multiple irrigation lines down each block allowed for irrigation treatments to be randomized within each block. Trees were watered every other day until June 3 then daily thereafter. Initial height and trunk diameter measurements were taken following planting in April 1996. Final measurements were taken in September 1996.

Table 1. Airspace, water-holding capacity, total porosity, and bulk density of container substrate.

\begin{tabular}{lll}
\hline Physical property $^{z}$ & $100 \%$ pinebark & $4: 1$ pinebark:coir \\
\hline Airspace & $32 \mathrm{a}^{\mathrm{u}}$ & $24 \mathrm{~b}$ \\
Water-holding $^{\mathrm{a}}$ & & \\
capacity $^{\mathrm{x}}$ & $51 \mathrm{a}$ & $58 \mathrm{~b}$ \\
Total porosity $^{\mathrm{w}}$ & $83 \mathrm{a}$ & $82 \mathrm{a}$ \\
Bulk density $^{\mathrm{y}}$ & $0.12 \mathrm{a}$ & $0.13 \mathrm{a}$ \\
\hline
\end{tabular}

${ }^{z}$ Substrate physical properties determined using the North Carolina State University Porometer.

yercent volume filled with air after substrate was saturated and allowed to drain for 60 minutes.

xPercent volume filled with water after substrate was saturated and allowed to drain for 60 minutes.

"Percent volume of substrate comprised of pore space.

"Ratio $\left(\mathrm{g} / \mathrm{cm}^{3}\right)$ of mass of dry solids to bulk volume of substrate.

"Mean separation within rows by Duncan's multiple range test,

$P=0.05$. Values are a mean of 5 observations.

\section{Experiment 2}

To simulate a pot-in-pot environment, plywood boxes were built and insulated with styrofoam insulation board, $2.54 \mathrm{~cm}$ ( 1 in.) thick, with a hole cut in the top of the box for container placement inside the box. An access door allowed for daily leachate collection. Six trees representing each irrigation and substrate treatment from Experiment 1 were placed in the above-ground pots.

Leachate volumes were recorded from the aboveground pots for each irrigation event. Leachates from three 2-week periods (June 5-18, July 12-25, and August 21-September 3, 1996) were evaluated separately with days used as replications. Soluble salts and $\mathrm{pH}$ were determined for each experimental unit monthly using the Virginia Tech Extraction Method (Yeager et al. 1983). Because pH was not affected by any treatments, data will not be presented. The General Linear Model procedure of the Statistical Analysis System (SAS Institute) was used in all analyses of variance.

\section{RESULTS AND DISCUSSION}

Total airspace was 33\% greater for $100 \%$ pinebark, while water-holding capacity was $12 \%$ greater for the pinebark:coir. Total porosity and bulk density were similar for both substrates (Table 1). Substrate physical properties were within acceptable ranges as reported by others (Bilderback 1980).

\section{Experiment 1}

Tree height and trunk diameter were affected by substrates and irrigation treatment, and there was no significant interaction $(P=0.05$ ) (Table 2). Tree height increase was about $23 \%$ greater with plants grown in the pinebark:coir substrate compared to the pinebark substrate. With trunk diameter, plants grown in pinebark:coir had a 50\% greater increase than plants grown in pinebark. Tree height and trunk diameter were also affected by irrigation treatment (Table 2). Plants grown with the 6-cycle treatment had a $21 \%$ greater height increase than plants irrigated with 1 cycle. Trunk diameter followed a similar trend with respect to irrigation treatments. These results support previous work showing an increase in growth with cyclic compared to a single application (Ruter 1997). There were no treatment effects on substrate $\mathrm{pH}$ and no fertilizer effects on growth (data not shown). Electrical conductivity was greatest for the cyclic irrigation 
treatments in August and September among irrigation

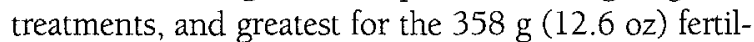
izer treatment in June and August among fertilizer treatments (Table 3).

\section{Experiment 2}

Irrigation application efficiency was affected by an irrigation $\times$ substrate interaction (Table 4). Irrigation application efficiency was greater for the 3- and 6cycle compared to the single application for all periods. These results are consistent with prior research

Table 2. Effects of irrigation and substrate on height and diameter increase of Quercus acutissima in a pot-in-pot production system.

\begin{tabular}{lll}
\hline Substrate & $\begin{array}{l}\text { Height increase } \\
(\mathrm{cm})\end{array}$ & $\begin{array}{l}\text { Trunk diameter } \\
\text { increase }(\mathrm{cm})\end{array}$ \\
\hline 100\% pinebark & $47.0 \mathrm{~b}^{\mathrm{y}}$ & $1.2 \mathrm{~b}$ \\
4:1 pinebark:coir & $57.9 \mathrm{a}$ & $1.8 \mathrm{a}$ \\
\multicolumn{2}{l}{ Irrigation treatment ${ }^{z}$} & \\
$6 \times$ & $57.9 \mathrm{a}$ & $1.7 \mathrm{a}$ \\
$3 \times$ & $52.1 \mathrm{ab}$ & $1.5 \mathrm{ab}$ \\
$1 \times$ & $47.8 \mathrm{~b}$ & $1.3 \mathrm{~b}$ \\
\hline
\end{tabular}

${ }^{2}$ Irrigation treatments were $2,160 \mathrm{~mL}$ applied in $\mathrm{l}$ application per day (1X), 3 applications per day of $720 \mathrm{~mL}$ (3X), and 6 applications per day of $360 \mathrm{~mL}(6 \times)$.

'Mean separation within columns by Duncan's multiple range test, $P=0.05$.

Table 3. Effects of irrigation, substrate, and fertilizer on electrical conductivity of Quercus acutissima in a pot-in-pot production system.

\begin{tabular}{llll}
\hline & \multicolumn{3}{c}{ Electrical conductivity $(\mathrm{dS} / \mathrm{m})$} \\
\cline { 2 - 4 } Substrate & June 29 & August 1 & September 14 \\
\hline $100 \%$ pinebark & $0.53 \mathrm{a}^{\mathrm{x}}$ & $0.59 \mathrm{a}$ & $0.33 \mathrm{a}$ \\
4:1 pinebark:coir & $0.58 \mathrm{a}$ & $0.63 \mathrm{a}$ & $0.34 \mathrm{a}$ \\
Irrigation treatment $^{y}$ & & & \\
$6 \times$ & $0.61 \mathrm{a}$ & $0.68 \mathrm{a}$ & $0.37 \mathrm{a}$ \\
$3 \times$ & $0.56 \mathrm{a}$ & $0.64 \mathrm{ab}$ & $0.36 \mathrm{a}$ \\
$1 \times$ & $0.51 \mathrm{a}$ & $0.52 \mathrm{~b}$ & $0.27 \mathrm{~b}$
\end{tabular}

Fertilizer treatment

\begin{tabular}{llll}
$179 \mathrm{~g}$ & $0.47 \mathrm{~b}$ & $0.35 \mathrm{~b}$ & $0.33 \mathrm{a}$ \\
$358 \mathrm{~g}$ & $0.65 \mathrm{a}$ & $0.88 \mathrm{a}$ & $0.34 \mathrm{a}$ \\
\hline
\end{tabular}

zElectrical conductivity determined by a YSI Model 35 Conductance Meter.

YIrrigation treatments were $2,160 \mathrm{~mL}$ applied in 1 application per day (1x), 3 applications per day of $720 \mathrm{~mL}(3 x)$, and 6 applications per day of $360 \mathrm{~mL}(6 \times)$.

Mean separation within columns by Duncan's multiple range test, $P=0.05$ showing increased irrigation application efficiency with cyclic irrigation (Tyler 1996; Ruter 1997). Irrigation application efficiency was greater for pinebark:coir compared to pinebark for all periods for the single application irrigation treatment. Irrigation application efficiency appeared to increase for the continuous treatment as the season progressed (data not shown), most likely as a response to increased plant needs. Irrigation application efficiency was $100 \%$ for the July $12-25$ and August 21September 3 periods for the cyclic treatments for both substrates. These data also suggest that maximum benefits from cyclic irrigation occurs early in the spring or when plants are recently repotted.

\section{CONCLUSIONS}

Cyclic irrigation increased irrigation application efficiency by reducing leachate volume. The addition of coir to pinebark substrate can increase irrigation application efficiency when a single irrigation event is used. Cyclic irrigation resulted in increased growth of Sawtooth oak compared to a single irrigation event (Table 2). With increasing emphasis on water quality and quantity used, growers might consider changing irrigation practices to improve irrigation

Table 4. Effect of a substrate $\times$ irrigation interaction on irrigation application efficiency ${ }^{z}$ when applied to Quercus acutissima in a pot-in-pot production system.

\begin{tabular}{|c|c|c|c|}
\hline \multirow[b]{2}{*}{ Substrate } & \multicolumn{3}{|c|}{ Irrigation treatment ${ }^{\mathrm{y}}$} \\
\hline & $1 \times$ & $2 x$ & $3 x$ \\
\hline \multicolumn{4}{|l|}{ June 5-June 18} \\
\hline $100 \%$ pinebark & $26.9^{z} \mathrm{cB}^{x}$ & $87.6 \mathrm{bB}$ & $95.2 \mathrm{aA}$ \\
\hline 4:1 pinebark:coir & $46.6 \mathrm{bA}$ & $92.5 \mathrm{aA}$ & 86.1 aA \\
\hline \multicolumn{4}{|l|}{ July 12-July 25} \\
\hline $100 \%$ pinebark & $80.2 \mathrm{bB}$ & $100 \mathrm{aA}$ & $100 \mathrm{aA}$ \\
\hline 4:1 pinebark:coir & $95.4 \mathrm{bA}$ & $100 \mathrm{aA}$ & $100 \mathrm{aA}$ \\
\hline \multicolumn{4}{|c|}{ August 21-September 3} \\
\hline $100 \%$ pinebark & $86.2 \mathrm{bB}$ & $100 \mathrm{aA}$ & $100 \mathrm{aA}$ \\
\hline 4:1 pinebark:coir & $90.7 \mathrm{bA}$ & $100 \mathrm{aA}$ & $100 \mathrm{aA}$ \\
\hline \multicolumn{4}{|c|}{$\begin{array}{l}\text { "Irrigation application efficiency }=\text { [(water volume applied - } \\
\text { water volume leached)/water volume applied]. } \\
\text { y.rigation treatments were } 2,160 \mathrm{~mL} \text { applied in } 1 \text { application } \\
\text { per day }(1 \times), 3 \text { applications per day of } 720 \mathrm{~mL}(3 \times) \text {, and } 6 \\
\text { applications per day of } 360 \mathrm{~mL}(6 \times) \text {. } \\
\text { xMean separation within rows (lower case) and within columns } \\
\text { for each } 2 \text {-week period (upper case) by Duncan's multiple range } \\
\text { test, } P=0.05 \text {. }\end{array}$} \\
\hline
\end{tabular}


application efficiency of container-grown trees. Nurseries need to especially be concerned early in the season when plants are not yet established. It is this time of year when there is less demand for water and fewer roots to take up nutrients. Considering most nurseries fertilize early in the season, it is this time of year that poor irrigation application efficiency can result in increased water quality problems from leaching of nutrients. Many growers of large container plants can apply cyclic irrigation methods without major changes in existing equipment.

\section{LITERATURE CITED}

Beeson, R.C., Jr. and G.W. Knox. 1991. Analysis of efficiency of overhead irrigation in container production. HortScience 26:848-850.

Bilderback, T.E. 1980. Container soils and soilless media. North Carolina Agricultural Extension Service. NCPM No. 9.

Bir, R.E. 1988. Water and container nurseries. Mountain Nursery Newsl. March:1.

Evans, M.R., and R.H. Stamps. 1996. Growth of bedding plants in sphagnum peat and coir dust-based substrates. J. Environ. Hort. 14:187-190.

Fare, D.C., C.H. Gilliam, G.J. Keever, J. Olive, and J.C. Stephenson. 1991. Nitrogen levels in irrigation effluent from container nurseries. Proc. South. Nur. Assoc. Res. Conf. 36:81-83.

Fonteno, W.C., C.T. Hardin, and J.P. Brewster. 1995. Procedures for determining physical properties of horticultural substrates using the NCSU Porometer. Horticultural Substrates Laboratory. North Carolina State University.

Gilbert, C.F, and D.S. Henry. 1988. Quercus acutissima 'Gobbler'. Amer. Nurseryman 168(3):122.

Karam, N.S., and A.X. Niemiera. 1994. Cyclic sprinkler irrigation and pre-irrigation substrate water content affect water and $\mathrm{N}$ leaching from containers. J. Environ. Hortic. 12:198-202.
Karam, N.S., A.X. Niemiera, and C.E. Leda. 1994. Cyclic sprinkler irrigation of container substrate affects water distribution and marigold growth. J. Environ. Hortic. 12:208-211.

Lamack, W.F., and A.X. Niemiera. 1993. Application method affects application efficiency of spray stakeirrigated containers. HortScience 28:625-627.

Martin, C.A., H.G. Ponder, and C.H. Gilliam. 1989. Effects of irrigation rate and media on growth of Acer rubrum L. in large containers. J. Environ. Hortic. 7:38-40.

McWilliams, D.A., T.D. Valco, H.D. Pennington, B.L. Harris, J.M. Sweeten, and W.B. Gass. 1991. Ground water protection. Amer. Nurseryman 174(10):80-83.

Parkerson, C.H. 1990. P \& P: A new field-type nursery operation. Proc. Inter. Plant Prop. Soc. 40:417-419.

Rehder, A. 1940. Manual of cultivated trees and shrubs. Macmillian, New York, NY.

Ruter, J.M. 1997. Pot-in-pot production and cyclic irrigation influences growth and evapotransporation of 'Okame' cherry. HortScience 32:546 (Abstr.).

Tyler, H.H., S.L. Warren, and T.E. Bilderback. 1996. Reduced leaching fractions improve irrigation use efficiency and nutrient efficacy. J. Environ. Hortic. 14:199-204.

Yeager, T.H., R.D. Wright, and S.J. Donohue. 1983. Comparison of pour-through and saturated pine bark extract N, P, K, and $\mathrm{pH}$ levels. J. Amer. Soc. Hortic. Sci. 108:112-114.

Department of Horticulture

Auburn University

101 Funchess Hall

Auburn, AL 36849

Corresponding author: Glenn B. Fain 
Résumé. Cette étude a été réalisée pour évaluer des techniques de production d'arbres en contenant de gros calibre à être utilisé en aménagement paysager urbain. Lobjectif était de minimiser les impacts environnementaux négatifs en augmentant l'efficience de l'irrigation, dès lors on réduisait ainsi le volume perdu par lessivage. Trois méthodes d'irrigation et deux substrats différents ont été évalués pour déterminer leurs effets sur l'efficience de l'irrigation et la croissance du chêne à dents pointues (Quercus acutissima Carruthers) cultivé dans une production pot-en-pot. L'efficience del'irrigation était accrue lorsqu'elle était effectuée de façon cyclique plutôt que sur une base continuelle était également accru lorsque le substrat écorces de pins-fibres de noix de coco était utilisé comparativement à celui d'écorces de pin seul. La croissance était supérieure lorsque l'irrigation était faite en six cycles plutôt que sur une base continue. Les arbres cultivés dans le substrat écorces de pin-fibres de noix de coco étaient plus gros que ceux cultivés dans l'écorce de pin seul.

Zusammenfassung. Diese Studie wurde durchgeführt, um Produktionstechniken für große Containerpflanzen, die in der Stadt eingesetzt werden sollen, zu bewerten. Das Ziel war es, die negativen Umwelteinflusse durch eine Vergesserung der Bewässerungstechnik zu erreichen und dabei den Wasseraustritt aus dem System zu reduzieren. Drei Bewässerungstechniken und zwei Substratbehandlungen wurden bewertet, um den Effekt auf die Effektivität der Bewässerungstechnik und Wachstum der Sägezahneiche (Quercus acutissima Carruthers) in einer Topf-in-Topf
Produktion zu bestimmen. Die Effizienz der Bewässerung wurde durch die zyklischen Behandlungen im Vergleich zu den kontinuierlichen gesteigert und durch RindenmulchKokosfaser-Mix gegenüber Rindenmulch ver-bessert. Das Eachstum war größer, wenn die Bewässerung in sechs Zyklen gegenüber einer kontinuierlichen Applikation durchgeführt wurde. Die Baüme in dem RindenmulchKokosfaser-Mix waren größer als die in dem Rindenmulchsubstrat.

Resumen. Este estudio fue conducido para evaluar las técnicas de producción de grandes árboles en contenedor para uso en el paisaje urbano. El objetivo fue minimizar el impacto ambiental negativo mediante el aumento en la frecuencia de riego, reduciendo de ese modo el volumen de pérdida de minerales. Fueron evaluados tres tratamientos de riego y dos tratamientos con substrato para determinar sus efectos sobre la eficiencia de aplicación de riego y el crecimiento del roble diente de sierra (Quercus acutissima Carruthers) en un sistema de producción maceta a maceta. La eficiencia de la aplicación del riego fue incrementada por el ciclo de tratamientos comparado con el tratamiento continuo y fue incrementada con el substrato de corteza de pino:fibra de coco en comparación con corteza de pino. El crecimiento fue mayor cuando el riego fue aplicado en seis ciclos que en aplicación continua. El crecimiento de los árboles en el substrato de corteza de pino:fibra de coco fue mayor que aquellos que crecieron en el substrato de corteza de pino. 